\title{
Review
}

\section{Good government: Democracy beyond elections}

\author{
Pierre Rosanvallon (trans. by Malcolm DeBevoise) \\ Harvard University Press, Cambridge, MA, 2018, 338pp., \\ ISBN: 978-0-674-97943-7
}

Contemporary Political Theory (2020) 19, S71-S74. https://doi.org/10.1057/s41296018-0264-x; published online 19 September 2018

The controversy over President Trump's 'zero-tolerance' immigration policy, which separated children from their parents, pointed to the central problematic of Pierre Rosanvallon's Good Government. Trump initially denied having the power to change the policy and called for Congress to change the laws governing how border agents process families. However, given the public outcry, he intervened himself and signed an executive order instructing agents to stop breaking families apart. The episode affirmed the outsized discretion of the president and the diminution of legislative power in most areas of decision-making.

Rosanvallon characterizes the current era as defined by presidentialism, in which democratic citizens are neither directly, nor through their elected representatives, part of the decision-making process. Instead, they can be said to be governed by executive authority. While he acknowledges how presidentialism satisfies a desire among the governed to pin down responsibility on a single person, he argues that this has come at the cost of good government. This is an unresponsive and undemocratic reality: decision-making is opaque and removed from the lives of ordinary citizens. The resulting disenchantment with government feeds either a retreat into the concerns and pleasures of private life or the appeal of political outsiders like Trump, who promise to clean up a political culture that is widely viewed as corrupt. The book's central contribution is a precise articulation of the problem that presidentialism poses to democratic freedom. While it begins to identify pathways for realizing greater freedom within this regime, it falls short since it does not tackle any of the challenges that any alternative institutions must anticipate - if they are to succeed.

Reviewing primarily French history, Rosanvallon shows how executive power was often identified with arbitrary rule. The rule of law emerged during the French Revolution as a safeguard against monarchs and depersonalized governmental power. Compared with the particularity of despotic rule, the rule of law promised fairness thanks to its generality: law was the product of parliament, applied equally

(C) 2018 Springer Nature Limited. 1470-8914 Contemporary Political Theory Vol. 19, S1, S71-S74 
and impersonally to all citizens, administered without prejudice. In short, the rule of law promised a just and more democratic political order. The years following the Revolution were marked by crisis, confusion, and parliamentary impotence that fed into public support for a counterrevolution. Rosanvallon sees Bonaparte as a pivotal figure in the history of presidentialism because he managed to concentrate power in himself while simultaneously projecting himself as a man of the people, who personified their will (p. 38). Bonaparte thus sketched a blueprint for subsequent populist leaders.

During the twentieth century, presidentialism came to enjoy consensus across political systems. How and why did this happen? First, the expansion of universal suffrage advantaged candidates who could appeal to and harness the power of crowds. Second, the First World War prioritized centralized and efficient decisionmaking, which elevated executive power over the legislative process. Finally, war and the expanded reach of the state into new corners of social life further magnified the power of the executive. Presidentialism responded to a desire for responsibility and accountability in relation to the growing size and complexity of the state and what was increasingly seen as the dysfunction of legislative bodies. The elevation of the executive satisfied social desires for greater legibility since decision-making appeared concentrated in a single body. Rosanvallon views these developments as inevitable, provided that the public's opposition to presidentialism gradually faded away. Still, he believes the acceptance of this shift came to pass without much reflection on its longer-term consequences.

Rosanvallon identifies the seeds of 'bad government' in tensions specific to presidentialism. To begin, candidates who make promises that they cannot, for various reasons, possibly keep once they are in office, win presidential elections. The failure to keep promises can fuel cynicism and disenchantment among a president's supporters and deepen their already weakened sense of trust in democracy. Equally problematic, presidentialism exacerbates the tension between the selection and legitimation functions of winner-take-all elections. It thus becomes possible for voters to declare the winner 'Not My President' if they doubt the candidate's legitimacy. The stamp of legitimacy conferred by an election victory can also license illiberal actions by the president against the press and their opponents, always in the name of the people. The danger here is that presidents can see their electoral victories, however small or huge, as mandating or justifying their actions.

The challenge is to rein in these features of presidentialism in order to make it more democratic. The paradox of the current era is that, while presidential power is more visible than ever, the inner workings of government institutions are opaque and more difficult to scrutinize. In effect, we have returned to the arbitrariness that typified the rule of monarchies. Good Government lays out five characteristics of what Rosanvallon refers to as 'permanent democracy', meant to ameliorate the feeling of voicelessness that citizens today report. 
In contrast to the periodic authorization that elections represent, Rosanvallon writes that permanent democracy involves constant interaction between the governed and their rulers. Permanent democracy seeks, in other words, to reconfigure the link between governors and the governed, to educate and involve citizens in decision-making by rendering the process more transparent - rather than expanding the sites of decision-making. Transparency is the overarching term that Rosanvallon uses to describe a regime that is more legible, responsible, and responsive to citizens. A regime may be judged transparent when it is possible for the governed to understand how decisions are made and hold their leaders accountable.

Rosanvallon calls for new institutions to play the role of restoring the relationship between the governed and the governing. He regards traditional political parties as bankrupt and untrustworthy. They are cut off from the daily concerns and experiences of ordinary citizens, too caught up in playing the game of winning elections. Alternatively, one option he proposes is a larger role for public interest research groups (PIRGs) that function in the US, combining advocacy, education, and organizing work around public issues, aiming to nurture public desires for greater transparency. Rosanvallon appears to assume that a capacity for good government remains intact on both sides of the governing relationship, though he admits that bad leaders and government are enabled by bad voters. What if we get the leaders we deserve though?

More frustrating though is the scant attention he pays to developments that have changed how leaders communicate with the governed - something that any alternative vision must address. These include leaders favoring social media over traditional outlets so as to communicate directly with constituents and maintain control of their 'message'. Such moves have the benefit of placing personality above policy, making leaders appear more genuine in the eyes of their supporters. Obama gave interviews to podcasters, appeared on YouTube comedy programs, and late-night TV programs, in order to get around the media filter. Trump famously uses Twitter to broadcast his policy changes to his followers. These leaders combine their politics with personal appeal, using 'sincerity' to cut through feelings of distrust. How might PIRGs navigate such a landscape? Good Government does not address this question. In fairness, the book is only a starting point for clarifying the challenges of our era. It is too much to expect for a single book to contain all the answers, especially given this is Rosanvallon's fourth installment of an attempt to map the history of our present political condition. It seems reasonable to hope that he will press further in his future work.

Taking stock of Good Government outside its own terms highlights the limits of its vision. There are few mentions of presidentialism in corners outside of France, with the exception of the UK, which is discussed in tandem with France and the US. Moreover, the development of presidentialism is presented as the latest stage of these nations' democratic histories, even if this stage is undemocratic or feels that

(c) 2018 Springer Nature Limited. 1470-8914 Contemporary Political Theory $\quad$ Vol. 19, S1, S71-S74 $\quad$ S73 
way to most citizens who are disenchanted with their leaders and the political process. Yet concentrated decision-making power in the hands of a centralized administrative authority ruling over a majority describes colonial rule. Was this a seed planted decades ago by some of these same democracies, now flowering on home soil? Put differently, what if bad government in these established democracies represents the after-life of imperialism? This is a testable hypothesis whose results may complicate the historical self-understandings that many democracies have of themselves, and I wonder what a wider historical lens might yield. Just as non-democratic outcomes in post-independence states might have been less of a break and more of a continuation of colonial rule by administrators and strong men, I wonder if presidentialism is an extension of the same principles. Democratic theorists might generally benefit from situating their inquiries about the future of democracy in frameworks that acknowledge the linkages between democracy and imperialism, both historically and its present-day forms.

Ali Aslam

Mount Holyoke College, South Hadley, MA 01075, USA aaslam@mtholyoke.edu 